THE science board of Britain's Science and Engineering Research Council (SERC) has given notice to the research community of how it wants to develop its new "active" research funding policy. "Clear industrial potential" seems to be one guiding principle. The board has drawn up a novel classification of the research it finances and has initiated reviews which, it claims, are already suggesting neglected areas.

In a policy statement published last week, $A$ strategy for support of core science, the board says that reviews being carried out by its separate committees stress the importance of access to advanced instrumentation and adequate provision of personnel. In chemistry, where the most progress has so far been made, the synthesis of new materials and the study of catalytic reactions at surfaces will receive a higher priority, while low-dimensional structures, protein engineering and chemical sensors are among interdisciplinary areas identified as "research themes" deserving more support. For biology, image-processing and neuroscience are short-listed priority areas.

The science board is the largest of the four main arms of SERC and finances research worth $£ 70$ million a year. But it has been under increasing financial pressure in recent years, and this has emphasized the need to take a more directive role in selecting research areas, according to its chairman, Professor John Cadogan. Research grants to university workers, for example, fell from $£ 24$ million in $1977-78$ to $£ 19.5$ million in 1982-83 (1982 prices), and 30 per cent of grant applications deemed worthy of "alpha" status are now going unsupported. The remainder of the science board's budget divides roughly equally between supporting research students and maintaining and developing central and regional facilities such as the synchrotron radiation source at Daresbury, Cheshire, and the central laser facility at the Rutherford-Appleton laboratory in Oxfordshire, as well as university installations. Cadogan is quite candid about his aim of securing a bigger slice of SERC's budget for the science board.

Many feel that astronomy and nuclear physics, each of which has its own board within the research council, are overrepresented on SERC's governing body. A recent proposal to merge them was dropped despite the personal backing of SERC's chairman, Professor John Kingman. Cadogan, an industrial chemist, is diplomatically noncommittal, suggesting that maybe the time was not right. But the failure of the idea will not have made his crusade for core science any easier.

The new strategy is an attempt to get away from the system used to assess grant applications before 1982, when each was assessed strictly on its own merits. Now the board will decide what the priority subjects should be, although it stresses that there will be continuing reviews.

It seems possible that in future more research with clear economic potential will be supported. Here the new strategy document appears somewhat uncertain. "It is not the science board's job or intent to support research specifically for industry", it declares boldly, adding, however, immediately afterwards that it "believes it must support core science in such a way that British industry prospers"' Nevertheless, the board insists, it remains a fundamental tenet of its philosophy that funds must be made available for "outstanding scientists" on any problem of "excellence, timeliness and promise". The idea of a special fund for such "blue sky" research was dropped, however.

The science board's most urgent priority now is to increase again the amount that it can spend on research grants, and a strong case along these lines is contained in SERC's submission to the Advisory Board for the Research Councils on scientific opportunities for 1985 . Something of the new subject strategy exercise has also found its way into this document, although the full impact will not be felt until next year's survey of opportunities for 1986. In the meantime, the details of "research themes" in most subjects are still being worked out, and the science board hopes its new document will be circulated widely and attract comment.

Tim Beardsley
Education in Canada

\section{Washington}

THE Science Council of Canada has joined the international stampede to declare the need for "sweeping" changes in the ways its schools teach science. In a new report for the Ministry of Science and Technology, the council says that most teachers are underqualified and that science textbooks and curricula present a picture of science so oversimplified that it is no longer authentic. Unlike a similar report published last year by the United States' National Science Board, however, the Canadian study claims that dramatic improvements can be made without large expenditure and by working through existing institutions.

The report's principal recommendation is that all elementary school children should receive science education as proposed in the official policy statements of provincial ministries of education. The Science Council concluded that these policies are seldom observed and that most children are given only "token"' exposure. The council is impatient with the argument of many elementary schools that science is "integrated" in other class activities, believing "integration" to be so vague as to be of little value. It says science should be taught as a specific subject for at least $\mathbf{1 0}$ per cent of the time.

Another major issue raised in the Canadian report is the quality of science textbooks. The council does not quarrel with their accuracy, but says they fail to convey a realistic sense of the way in which research is conducted and of the link between science and technology. Peter David

\title{
Kew palms off its Victorian critics
}

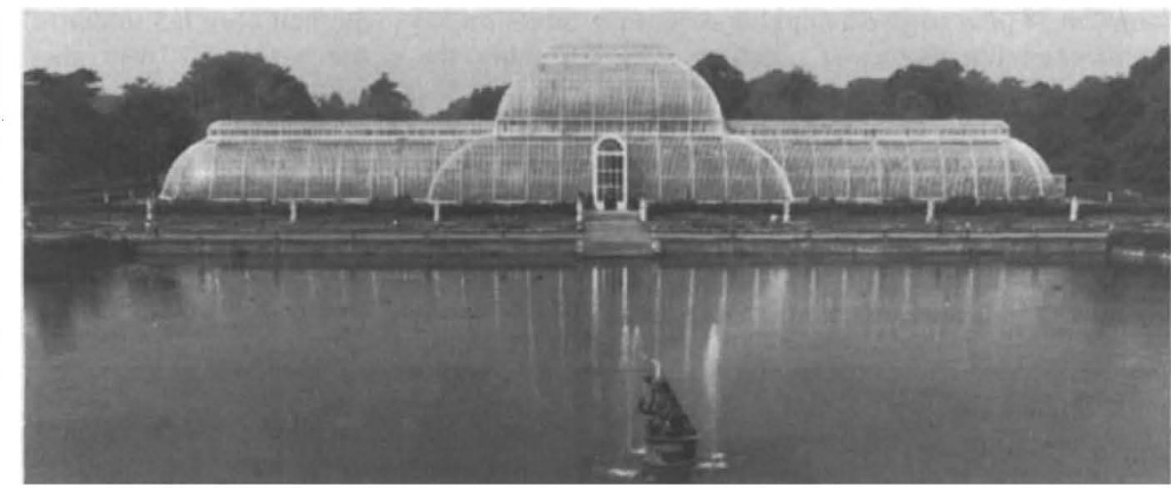

THE normally serene surroundings of the Royal Botanic Gardens at Kew, on the outskirts of London, have been rudely disturbed in recent months.

Bitter arguments have raged over plans largely to reconstruct the outstanding 19 thcentury palm house (above), designed by Richard Turner and Decimus Burton and the inspiration for tropical plant houses the world over.

The building is in poor structural condition and now has to be painted every two years, while 600 panes of specially curved glass have to be replaced annually. But renovation plans put forward by the Property Services Agency of the Department of the Environment have aroused the ire of the Victorian Society, among others. The existing wrought-iron glazing bars will have to be replaced with stainless steel, because wrought iron is not now available in sufficient quantity.

Some sort of compromise on the scheme has now been reached. But the Garden History Society is still unhappy with plans to increase the extent of the plant beds and so cover the iron grating floor, although the plants grow best in beds. Tim Beardsley 